\title{
The Risks of Investments in Transport Infrastructure Projects
}

\author{
O. Pokorná, D. Mocková
}

Investment decisions should not be taken without an in-depth analysis of the risks. This is an important stage in project preparation and should be performed simultaneously with the planning of the financial operations. Infrastructure development requires that project risks and responsibilities be assigned to the public or private entity that is best able to manage them. The risks and their financial impacts are usually not quantified equally by all parties. Each party views the given risks according to the guarantees provided. These guarantees are related to the form of participation in the project.

Keywords: project financing, identification of risks, construction phase risks, star-up and operating phase risks, risk analysis, investment decisions, financial evaluation of the risks.

\section{Introduction}

Risk allocation is a complex and difficult process, and for all practical purposes, it is a negotiated process.

The study of risks should consist of two stages:

- Identification of the sources of risks.

- Detection of the financial consequences of these risks for the stakeholders and investors.

\section{Identification of risks}

A variety of risks can occur during the construction phase and operation phase of a project. The risks that can have a direct impact on the profitability and credibility of the project should be identified.

Identification of risks and risk management is a crucial part of project financing. Different risks can occur during different projects. Therefore the risks must be identified and allocated among the stakeholders of the project. The golden rule is that the actor who is best able to control, influence and manage the risk should bear the risk. This is often not the case in reality. Risk allocation is a comprehensive and a complicated process.

The problem can be illustrated by legal risks, which are often borne by the private sector, albeit only the public sector controls them. We can also mention inflation and interest rates, which the national bank oversees for. The risks of changes in them are often borne by the creditors, investors and shareholders. There are many other risks that are not borne by subjects who are in a position to manage them appropriately.

The extent of an individual risk can change over time. A feature of successful projects is that the risks are widely shared by the public and private sector. Generally it can be said that the private sector is better able to manage commercial risks and the responsibility associated with construction, operation and financing. On the other hand in the field of transport the public sector must be involved in many issues like right of way, political risks and sometimes also traffic and revenue risks.

In the context of project financing, a private company should have access to adequate resources and experience to carry out the construction effectively with future backflow from the collection of tolls. It may then be possible for the company to bear the construction risk and some part of the traffic risk. The public entity would bear responsibility for guarantees and subsidies in the case of insufficient traffic intensity when operation begins.

The main risks facing infrastructure projects are pre-construction activity, construction, traffic and revenue, currency, force majeure, tort liability, political risk and financial risk. These risks must be addressed in a satisfactory manner before debt and equity investors will commit to project funding. The standard risks identified in contracts are: pre-construction, construction, traffic and revenue, financial, regulatory and political. In addition, force majeure and legal liability are commonly addressed in contracts since they have proven to be serious sources of cost overruns in the sector.

\subsection{Construction phase risks}

During this phase, the major risks are delays in completion and the commencement of project cash flows; cost overruns with an increase in the capital needed to complete construction; and insolvency or lack of experience of contractors or key suppliers.

Construction costs may exceed estimates for many reasons, including inaccurate engineering and design, escalation in material and labour costs, and delays in project start-up. Cost overruns are typically handled through a fixed-price and fixed-term contract, with incentives for completion and for meeting pre-specified investment goals. Other alternatives include provision for additional equity injections by the sponsor or standby agreements for additional debt financing. It is always sensible for developers to establish an escrow or contingency fund to cover such overruns.

Delays in project completion can result in an increase in total costs through higher capitalized interest charges. They may also affect the scheduled flow of project revenues necessary for debt servicing and operating and maintenance expenses.

\section{Availability of materials and equipment}

In many developing countries, the risk of equipment or materials for construction or operation must be considered. Transit bottlenecks, tariffs, foreign currency fluctuations and other factors can cause a significant increase in costs. 


\section{Contractor capability}

The main contractors and key subcontractors should have the experience, reputation, financial, technical and human resources to be capable of completing the project in a timely fashion on budget. This risk is best addressed through tough pre-qualification of bidders; through certification and monitoring; and by ongoing financial supervision of the contracting companies, to make sure that poor results from other projects or from weak balance sheets do not spill over into the specific project in question.

\section{Environmental and land risks}

Transport projects can have a substantial environmental impact. Such projects frequently attract strong opposition from community and environmental groups over issues of pollution, congestion, neglect of public transport and visual impact. Similarly, land acquisition can be a protracted process with the potential for extensive legal delays. In general, the public sector often takes on the responsibility for most of these risks since often it is easier for the public sector to take responsibility for acquiring rights-of-way, to pay for them and contribute this asset to the project. Project sponsors often try to ensure that the government bears the risk of providing all necessary land within a given time frame or being liable for damages. Furthermore, the cost of land acquisition can become a major factor where land values rise rapidly or are subject to speculative activity over which the project developer has no control. In these cases, agreement on some form of cost ceiling may be necessary in the concession contract. Generally, the host government should ensure that required licenses and permits be obtainable without unreasonable delay or expense.

\subsection{Start-up and operating phase risks}

The major risks for transport projects in these stages relate to traffic/revenue risk; regulatory and legal changes; interest rate and foreign exchange risks; force majeure risk; and political risk.

\section{Technology risks}

Project finance participants cannot ignore new technologies since these can either significantly improve the profitability of a project, or can adversely affect any project that uses obsolete technology. For example, the use of automatic toll collection technology reduces collection costs and incentives for graft. Another example is technological improvements in customs processing, so that border crossings on major arterial toll roads can be traversed more quickly, saving time for users and making the road more valuable.

\section{Traffic and revenue risks}

Demand risk is a major issue in virtually all projects. Even where there is a reasonable level of confidence in forecasts, demand can be dramatically affected by competition from other modes or facilities, changing patterns of use, and macroeconomic conditions.

These issues, over which the project sponsor often has little or no control, are very difficult to predict and represent a major risk to financing. In particular, forecasting during early years can be quite subjective. To the extent that these risks are driven by economic conditions, there is a potential role for the government to play in risk sharing, either through traffic or revenue guarantees or though other forms of support.

Since infrastructure construction often brings major structural changes for the region (the Channel Tunnel, high-speed railways) prediction of consumer behavior is not commensurate with the aggregate demand prognosis model. The issue is more complicated in the case of cross-border flows, where the border effect can appear.

Another typical feature is over-optimistic forecasting in order to convince a potential partner of the value of the project or, alternatively to get the deal at any price and renegotiate it afterwards.

Toll roads provide an illustration. Traffic volumes are very sensitive to income and economic growth, and the failure to recognize this may be one of the main reasons why so many toll road projects have failed.

\section{Financial risks: interest rates}

Financial risk is the risk that project cash flows may be insufficient to cover debt servicing and then to pay an adequate return on sponsor equity. Financing constraints, especially the lack of long-term debt capital, are a significant hindrance to toll road development. Only a few projects are able to generate returns on investment sufficient to attract private capital. This suggests that only a limited number of projects will be executed without massive state support.

Since in infrastructure we are concerned with long-term investments with high start-up costs, countries with local capital markets capable of providing long-term capital have an advantage. Of particular importance is the availability of mature domestic finance. In many countries infrastructure projects have been unable to obtain finance for more than 5 to 6 years, bringing other risks of renegotiations and refinancing. Such projects are not viable without government guarantees.

In theory, financial risk is best borne by the private sector. However in transport projects this risk is likely to be shared by the public sector, either in the form of debt or revenue guarantees, or by participation of the state or of an international financial institution. This can also take a form of a direct subsidy, grant or financial contribution, which will serve to improve the rate of return for the private sector.

\section{Currency risk}

Currency risk relates to the impact of the local currency exchange rate on the value of the investment. Moreover there is a question of the convertibility of the local currencies. This is a major risk in countries where, for example, the tolls are collected in a weak local currency.

\section{Force majeure risk}

Neither they public sector nor the private sector can influence or control some risks like earthquakes and floods, which impair the ability of the project to earn revenues. For the private sector there is some insurance available, but the public sector generally has to bear this risk and redesign the project as need be. The rule is that the remedies in these cases should be essential part of the contract. 


\section{Regulatory and legal risks}

The issues of regulation and subordination to the regulatory authority should be dealt with in the contract. This should apply to the extent of the authority's power and its responsibility concerning the fees charged, public commitments and an environment of equal competition. This matter can affect the value of the business, which can be sensitive to the revenue earned. Therefore clear rules should be set and the way in which the regulatory authority exercises them should be verifiably independent.

But even if regulatory rules are clear enough, they are only as effective as the regulators can be. The best-designed regulatory environment is useless if the regulator is not independent or fair. The pressures on regulators can be a major source of concern.

Project finance structures typically cover periods of ten years or more. The relevant legal and regulatory environment is likely to change substantially over that period. The rules dealing with the financial consequences of these changes between government, users and operators are critical, but are often ignored. The rules must cover the possibility of adjusting the contract terms during the project-financing period.

\section{Political risks}

Political risks concern government activities that could affect the ability to generate revenues. These could include termination of concessions, additional taxation and regulation, which then impair the value of the project for the investors, or even the nationalization of private property. Ideally the government guarantees concerning these risks, and the method of compensation for lost profit, should form part of the contract. In some cases insurance provided by an international financial institution should be a requisite.

\section{Risk analysis}

Risk analysis is involves quantifying the risk of each variant examined followed by proposal and design of corrective measures that will strengthen the probability of the project's success.

Risk analysis can be divided into the following phases:

- Identification of the factors that influence the decision criteria

- Determination of the functionality of the decision criterion on the factors

- Determination of the probability density function of the risk factors

- Construction of the probability density function of the decision criteria considered

- Evaluation of the risks of the project.

In order to perform risk analysis we have to know the decision criteria. If there is more than a single decision criterion, the analysis solves the comprehensive problem of how to express the total risk taking into consideration all evaluation criteria.

The most common investment decision is risk analysis taking into consideration only one decision criterion - the economic evaluation of the efficiency of the investment.

\section{Financial evaluation of risks}

The risks and their financial impacts are usually not quantified equally by all parties. Each party views the given risks according to the guarantees provided. These guarantees are related to the form of participation in the project. Mostly this concerns the basic capital provided by the stakeholders, debts guaranteed by the shareholders, non-guaranteed debts (the risk is borne by a financial institution), and the resources provided or guaranteed by the public sector. Stakeholders and banks mostly cover financial risks. The recovery priority is always debt servicing after, which comes satisfying the shareholders. The greater the risk they undertake, the higher return on capital they naturally expect.

Evaluation of the risks is performed by independent bodies and experts, who assess all aspects of the project (technical, legal, commercial and fiscal). Sensitivity analyses are performed for these purposes. These attempt to measure the impacts on the anticipated profitability of the project of different parameter changes: exchange rate deviation, interest rate changes, inflation, and construction delays, underestimated traffic intensities. The results of the sensitivity analysis form the basis for the variants, which lead to the risk evaluation. Through the use of these probabilities future cash flows are thus constructed.

\section{Conclusion}

The main risks facing infrastructure projects include pre-construction, construction, traffic and revenue, currency, force majeure, tort liability, political, and financial factors. These risks must all be addressed in a manner satisfactory to debt and equity investors before they will commit to project funding.

Project finance transactions are typically governed by a nexus of long-term formal contracts, written between the project promoter, the host country government, creditors, input suppliers, contractors, operators, and service providers. Three classes of contracts are important: concession agreements that stipulate a property rights transfer from the government to the project company, performance contracts between the project company and contractors and operators, and loan contracts between creditors and the project company. Such contracts are designed to share risk and to protect contracting parties against opportunistic "hold-up" behaviour by others. In practice, they address two important characteristics of infrastructure investments: a high degree of asset specificity; and large project-specific risks that cannot be diversified in financial markets.

In such "relationship-specific" investments, investors are hesitant to make investments without adequate contractual protection. Once the investment is sunk, the incentive system and the bargaining power of the contracting parties change vis- -vis each other. Anticipating such an outcome, project promoters often insist on governments providing various kinds of guarantees to cover a range of risks.

\section{References}

[1] Estache, A., Strong J.: The Rise, the Fall, and ... the Emerging Recovery of Project Finance in Transport. World Bank Institute 
[2] Gannon, M. J.: Risk Analysis and its Application within the Private Finance Initiative. The Proceedings of The Chartered Institute of Transport in the UK, 7/1998

[3] Thompson, J. L.: Strategic management. Chapman \& Hall, London 1993

[4] Johnson, G., Scholes, K.: Exploring corporate strategy. Prentice Hall International, 1993

[5] Babbar, S., Fisher, G.: Private Financing of Toll Roads. World Bank's Project Finance and Guarantees Group

[6] Kolektiv pracovníků Dopravní fakulty ČVUT: Alternativni možnosti financováni železničnich koridorü. ČVUT, Praha 1998
[7] Pokorná, O.: Zdroje financováni dopravni infrastruktury. Diplomová práce, Praha 2001

Ing. Denisa Mocková

phone: +420224359160

fax: +420224919017

e-mail:mockova@fd.cvut.cz

Ing. Olga Pokorná

phone: +420251431059

e-mail: pokorna@mdcr.cz

Czech Technical University in Prague

Faculty of Transportation Sciences

Horská 3

12803 Praha 2, Czech Republic 